\title{
PKM Pembuatan Sabun Batang Dari Limbah Minyak Jelantah Bagi IRT Kelurahan Muara Fajar Kota Pekanbaru
}

\author{
Delovita Ginting*, Shabri Putra Wirman, Yulia Fitri, Neneng Fitrya, \\ Sri Fitria Retnawaty, Noni Febriani \\ Program Studi Fisika, Universitas Muhammadiyah Riau \\ email: delovita@umri.ac.id
}

\begin{abstract}
A product called soap can be obtained from the hydrolysis reaction of fatty acids with bases (alkalis). One source of fatty acids that are often found in everyday life is cooking oil. The rest of the cooking oil that has been used is directly discharged into the environment around the house without going through the processing first. Lack of knowledge and public awareness of the dangers of direct cooking oil waste disposal is one of the reasons for the physics study program to devote housewives to the estuary dawn village of Pekanbaru City. This village is located close to the lake where the lake water is widely used as a source of clean water for residents. Lake is also a natural biota that has a variety of biological life in it. The aim of this service is to provide information to the housewife of the dangers of disposing waste cooking oil and to provide training in making soap by utilizing waste cooking oil into soap products that can be reused for washing in daily life..
\end{abstract}

Keywords: Cooking Oil Waste, Soap, Environmental Health, biota, Public Service

Abstrak

Produk yang disebut sabun dapat diperoleh dari reaksi hidrolisis dari asam lemak dengan basa (alkali). Salah satu sumber asam lemak yang sering dijumpai dalam kehidupan sehari-hari yaitu minyak goreng. Sisa minyak goreng yang telah digunakan langsung dibuang ke lingkungan sekitar rumah tanpa melalui proses pengolahan terlebih dahulu. Kurangnya pengetahuan dan kesadaran masyarakat terhadap bahaya pembuangan limbah minyak goreng secara langsung menjadi salah satu alasan bagi program studi fisika untuk melakukan pengabdian kepada ibu rumah tangga pada kelurahan muara fajar kota pekanbaru. Kelurahan ini berlokasi dekat dengan danau di mana air danau tersebut banyak digunakan untuk sumber air bersih bagi warga. Danau juga merupakan biota alam yang memiliki berbagai aneka ragam kehidupan hayati di dalamnya. Tujuan dari pengabdian ini memberikan informasi kepada Ibu Rumah Tangga bahaya membuang limbah minyak jelantah dan memberikan pelatihan pembuatan sabun dengan memanfaatkan limbah minyak jelantah menjadi produk sabun yang dapat digunakan kembali untuk mencuci dalam kehidupan sehari-hari.

Kata Kunci: Limbah Minyak Goreng, Sabun, Kesehatan Lingkungan, biota, Pengabdian Kepada Masyarakat

\section{PENDAHULUAN}

Limbah minyak goreng atau yang kita kenal dengan istilah minyak jelantah adalah minyak yang diperoleh dari sisa proses penggorengan.

Berdasarkan data Badan Pusat Statistik (BPS) konsumsi minyak goreng mengalami peningkatan dari tahun ke tahun.
Peningkatan konsumsi minyak goreng pada akhirnya akan berdampak terhadap semakin meningkatnya limbah minyak goreng atau minyak jelantah yg dihasilkan.

Limbah minyak goreng atau minyak jelantah memiliki dampak negatif terhadap lingkungan. Potensi limbah minyak jelantah menjadi sangat besar karena belum maksimal penggunaannya sehingga dapat menjadi air limbah domestik. Keputusan 
Menteri Negara Lingkungan Hidup Nomor 112 tahun 2003 tentang baku mutu air limbah domestik, yang dimaksud dengan air limbah domestik adalah air limbah yang berasal dari usaha dan atau kegiatan pemukiman, rumah makan, perkantoran perniagaan, apartemen dan asrama.

Dampak pembuangan minyak jelantah yang paling sering dirasakan oleh masyarakat atau ibu rumah tangga adalah minyak dapat membeku di pipa saluran air buangan, sehingga membuat pipa buangan jadi tersumbat. Masalah besar lain yang dihadapi jika limbah minyak goreng dibuang secara sembarangan ke lingkungan dapat menyebabkan pencemaran bagi lingkungan.

Limbah minyak goreng atau minyak jelantah yg dibuang ke perairan dapat menyebabkan rusaknya ekosistem perairan karena meningkatnya kadar Chemical Oxygen Demind (COD) serta Biological Oxygen Demind (BOD) yang disebabkan tertutupnya permukaan air dengan lapisan minyak sehingga sinar matahari tidak dapat masuk ke perairan, akibatnya biota-biota perairan mengalami kematian yang akhirnya akan mengganggu ekosistem perairan tersebut (Abduh, 2018).

Ibu rumah tangga adalah masyarakat yang paling dominan menggunakan minyak jelantah, sehingga penting untuk mereka mendapat pengetahuan dan informasi dampak bagi kesehatan dan lingkungan. Pengabdian kali ini akan memberikan edukasi bahaya penggunaan minyak jelantah berulang dan bahaya membuang minyak jelantah ke lingkungan bagi IRT kelurahan muara fajar timur dan barat. Lokasi pengabdian ini berada dekat dengan danau yang airnya banyak digunakan sebagai sumber air bersih bagi warga. Berdasarkan penjelasan di atas program studi fisika melakukan program pengabdian kepada masyakarakat sosialisasi bahaya limbah minyak jelantah bagi lingkungan dan memanfaatkan limbah minyak jelantah sebagai bahan baku pembuatan sabun.

\section{METODE PENGABDIAN}

Metode pelaksanaan kegiatan pengabdian ini terdiri dari dua tahap:

1. Tahap Persiapan

Pada Tahap ini dilakukan koordinasi dengan ketua RT dan Ibu PKK di Keluarahan muara fajar barat dan timur.

2. Tahap sosialisasi:

Tahap mempersiapkan materi pentingnya kesehatan lingkungan dengan mengumpulkan informasi pentingnya menjaga kesehatan lingkungan yang dekat dengan keadaan masyarakat. Membuat slide presentasi bahaya dan dampak pembuangan minyak jelantah bagi lingkungan.

3. Tahap Pelatihan Pembuatan Sabun

Pada tahap berikutnya tim melakukan persiapan alat-alat dan bahan yang akan digunakan dalam pembuatan sabun batang. Kegiatan dilanjutkan dengan membuat modul cetak yang akan ditinggalkan untuk dapat digunakan kembali oleh ibu rumah tangga kelurahan muara fajar. Pada tahap ini Ibu rumah tangga kelurahan muara fajar barat dan timur diberikan pelatihan bagaimana mengolah minyak jelantah menjadi sabun yang dapat digunakan untuk mencuci pakaian dan sebagainya.

4. Tahap Evaluasi

Di akhir kegiatan, evaluasi dilakukan untuk dapat menyimpulkan dan menilai kesesuaian kegiatan yang berlangsung terhadap rancangan awal kegiatan.

\section{HASIL DAN PEMBAHASAN}

Berdasarkan diskusi dengan ketua RT keluarahan muara fajar barat dan timur ditetapkan beberapa kesepakatan agenda pelaksanaan kegiatan. Kegaiatan koordinasi dilaksankan pada tanggal 23 Oktober 2019 dihadiri oleh ketua PKK, Ketua RT dan Ketua RW kel muara fajar. 


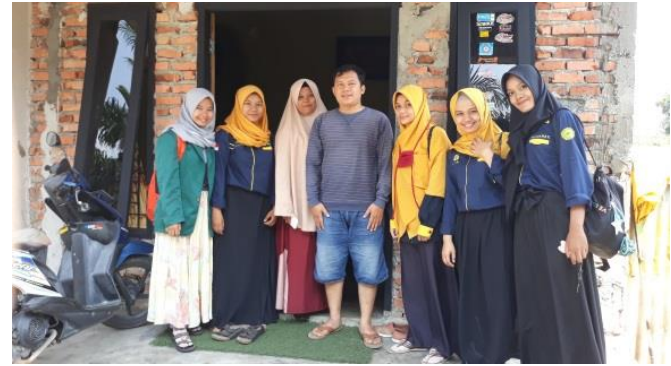

Gambar 1. Koordinasi dengan ketua RT muara fajar

Selajutnya penyampaian materi tentang kesehatan lingkungan oleh tim pelaksana yang merupakan mahasiswa fisika yang telah mengambil mata kuliah Kesehatan Lingkungan pada Program studi Fisika. Mahasiswa didampingi dosen sebelumnya mempersiapkan materi berupa PPT untuk disampaikan kepada peserta.

Tim pelaksana yang telah mempersiapkan bahan baku pembuatan sabun dan prosedur pembuatan sabun mendemonstrasikan prosedur pembuatan sabun. Peserta dapat mengikuti langsung setiap tahapan pembuatan sabun dengan menggunakan bahan-bahan yang telah dipersiapkan oleh tim pelaksana.

Adapun bahan-bahan yang digunakan dalam pembuatan sabun adalah minyak jelantah, larutan $\mathrm{NaOH}$, arang aktif dan fragrance atau pewangi sesuai keinginan. Alat-alat yang dibutuhkan dalam pembuatan sabun adalah wadah, saringan, timbangan dan wadah untuk mencetak sabun.

Tahapan dalam pembuatan sabun yaitu pada tahap awal minyak jelantah dimurnikan terlebih dahulu dengan menggunakan arang aktif dari arang kayu didiamkan selama 1 malam (arang dan minyak dengan perbandingan 1:4). Minyak jelantah yang sudah murni disaring kemudian ditambahkan $\mathrm{NaOH}$ hingga mengental. Untuk mendapat sabun yang wangi kita menambahkan dengan fragarance oil kemudian sabun siap dicetak sesuai keinginan. Jemur sabun di bawah sinar matahari agar terbentuk padat, setelah padat lepaskan sabun yg padat dari cetakan dan sabun sudah bisa digunakan.

Peserta ibu rumah tangga yang mendapatkan sosialisasi tentang kesehatan lingkungan memberikan respon positif dengan mengungkapkan beberapa kendala dan kesulitan yang mereka hadapi untuk memperoleh lingkungan yang bersih sehingga terhindar dari bahaya kesehatan yang buruk.

Pada Tahap pembuatan sabun peserta terlihat antusias dan merasakan kegiatan ini sangat bermanfaat untuk diterapkan karena dapat memanfaatkan limbah minyak jelanta yang biasanya dibuang begitu saja ternyata dapat dimanfaatkan menjadi sabun yang lebih bermanfaat. Peserta berharap ada pelatihan serupa untuk beberapa limbah rumah tangga yang belum dimanfaatkan ketersediannya, sehingga tidak mengganggu lingkungan dan memiliki nilai lebih dan manfaat lebih.

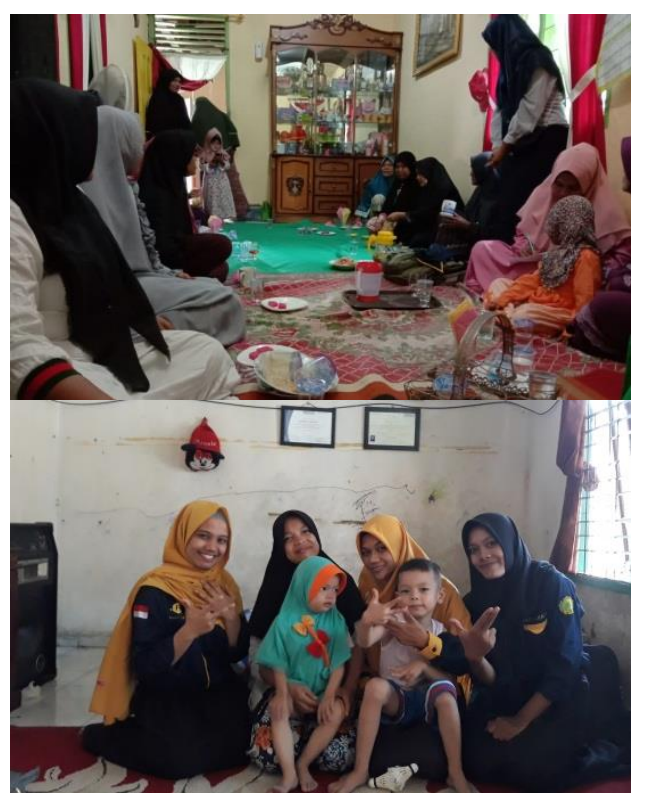

Gambar 2. Tahap sosialisasi dan pelatihan pembuatan sabun
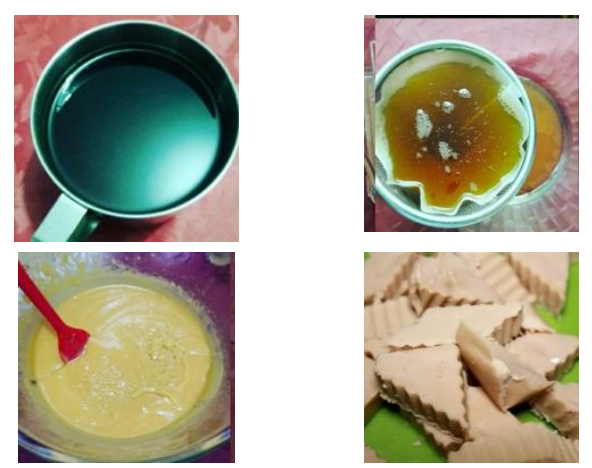

Gambar 3. Proses Pembuatan Sabun 


\section{SIMPULAN}

Pelatihan dan sosialisasi pemanfaatan limbah minyak jelantah diharapakna dapat mengurangi penggunaan minyak goreng berulang-ulang yang dapat membahayakan kesehatan manusia. Penanganan atau pembuangan minyak jelantah dengan memanfaatkan minyak jelantah menjadi produk sabun yang dapat digunakan untuk mencuci dalam kehidupan sehari-hari. Selanjutnya dapat dilakukan pengabdian masyarakat untuk pengembangan pemanfaatan sabun tidak hanya digunakan namun dapat menjadi sumber pemasukan bagi ibu rumah tangga.

\section{UCAPAN TERIMA KASIH}

Pelaksana berterimakasih kepada ketua RT dan ketua PKK keluarahan muara fajar timur dan barat. Kepada Ibu Nurmala yang telah bersedia menyediakan tempat untuk diadakan pengabdian ini. Kepada mahasiswa Fisika yang menjadi pelaksana dan panitia pada program PKM ini.

\section{DAFTAR PUSTAKA}

[1]. Statistik, B. P. 2018. Statistik RataRata Konsumsi per Kapita Seminggu Beberapa Macam Bahan Makanan Penting, 2007-2018. Jakarta: Badan Pusat Statistik.

[2]. Keputusan Menteri Negara Lingkungan Hidup Nomor 112 Tahun 2003 Tentang Baku Mutu Air Limbah Domestik.

[3]. Abduh, I.M.N. and Si, M., 2018. Ilmu Dan Rekayasa Lingkungan (Vol. 1). Sah Media.

[4]. Priani, S.E. and Lukmayani, Y., 2010. Pembuatan Sabun Transparan Berbahan Dasar Minyak Jelantah Serta Hasil Uji Iritasinya pada Kelinci. Prosiding SNaPP: Sains, Teknologi, 1(1), pp.31-48. 